„Bohemistyka” 2019, nr 4, ISSN 1642-9893

Katarzyna DEMBSKA

DOI: $10.14746 /$ bo.2019.4.2

Uniwersytet im. Mikołaja Kopernika

\title{
Eufemizacja w przekladzie (na materiale języka czeskiego)
}

Keywords: euphemization, taboo, translation, Czech language, Polish language Słowa kluczowe: eufemizacja, tabu, przekład, język czeski, język polski

\section{Abstract}

This article deals with the concept of euphemization in translation from Czech to Polish. The study material consists of excerpts from literary classics written in the Czech language obtained from the parallel corpus InterCorp, which constitutes an integral part of the Czech National Corpus and provides an opportunity to analyse texts with respect to translation equivalence.

The author concentrates on the methods of translation of two selected lexemes (srát, dèvka) and a prepositional phrase (do prdele) which are registered in Czech dictionaries and are qualified as vulgar or rude. Upon the analysis it emerged that the majority of translators 'hygienize the meaning' in translation, avoiding straightforward equivalence of the problematic lexemes by applying the process of euphemization, the outcome of which, though, is not always a euphemism sensu stricto (lexical unit).

In the presented article an attempt is made at establishing the reasons for the said process.

Niniejszy artykuł dotyczy zagadnienia eufemizacji w przekładzie z języka czeskiego na polski. Materiał badawczy został wyekscerpowany z czeskojęzycznej literatury pięknej za pośrednictwem korpusu językowego InterCorp, stanowiacego integralną część Czeskiego Korpusu Narodowego i dającego możliwość analizy tekstów pod względem ekwiwalencji przekładowej.

Autor skoncentrował swoją uwagę na sposobach przekładu dwóch wybranych leksemów (srát, děvka) oraz wyrażenia przyimkowego (do prdele), które są rejestrowane w słownikach języka czeskiego z kwalifikatorem wulgarności lub grubiańskości. Analiza wykazała, że większość tłumaczy dokonuje tzw. „higienizacji przekładu”, unikając bezpośredniej ekwiwalencji kłopotliwych leksemów przy zastosowaniu procesu eufemizacji, czego rezultatem nie zawsze jest jednak eufemizm sensu stricto (jednostka leksykalna).

W prezentowanym artykule została podjęta próba ustalenia przyczyn powodujących omawiany proces. 
Eufemizacja (proces łagodzenia wypowiedzi zawierającej treść uznawaną przez nadawcę za objętą tabu językowym w planie wyraża$n^{1}{ }^{1}$, niestosowną, kłopotliwą bądź niepożądaną) i eufemizmy (jako rezultat eufemizacji) od wielu lat stanowią przedmiot badań lingwistów zajmujących się słowiańskim obszarem językowym² ${ }^{2}$ Na gruncie czeszczyzny ów temat nie doczekał się jednak żadnego szerszego opracowania. Niniejsze artykuł jest zatem próbą ,zagospodarowania” tego - jak wynika ze wstępnych badań - urodzajnego terenu badawczego, choć zaledwie $\mathrm{w}$ jednym $\mathrm{z}$ jego fragmentów, a mianowicie sztuce przekładu.

Należy jednak podkreślić, że eufemizacja to proces, który nie zawsze prowadzi do powstania stricte eufemizmu (jednostki leksykalnej). W niniejszym artykule za eufemizm będzie uznawana jednostka leksykalna będąca charakterystyką „nie wprost”, łagodząca i często jednocześnie kamuflująca treść wypowiedzi.

Najczęściej występuje ona w postaci jedno- lub dwuelementowej bądź w formie związku frazeologicznego. Z wyrażeniami przezeń zastępowanymi łączy eufemizm związek synonimii lub quasi-synonimii. Jest zazwyczaj notowany w słownikach (choćby żargonu) i rozumiany przez nosicieli języka (choćby określoną grupę społeczna, np. młodzież) nawet, kiedy występuje bez szerszego kontekstu (Dembska 2007, s. 12)

Rozróżnienie terminu eufemizacja i eufemizm wydaje się szczególnie ważne w badaniach przekładoznawczych przy uwzględnieniu tendencji, by proces thumaczenia polegał przede wszystkim na przekazaniu sensu, a nie transferze słów. Teresa Tomaszkiewicz stoi na stanowisku, że

${ }^{1}$ Tabu w planie wyrażania wiąże się z tym, ,iż nałożenie tabu na wyraz (za pomocą którego uzewnętrzniany jest temat) nie pociąga za sobą koniecznie rezygnacji z samego tematu, bo zakazane wyrażenia można zastapić eufemizmami" (Leszczyński 1988 , s. 28)

${ }^{2}$ Zob. na przykład: Crnek 1927; Ларин 1961; Widłak 1963; Видлак 1967; Engelking 1984; Dąbrowska 1994; Крысин 1996; Алексеенко 1999; Dembska 2007; Czyżewski, Tyrpa 2008; Sojda 2012; Szymczak-Rozlach 2014.
[...] przekład to inaczej przełożenie, przeniesienie z jednego miejsca, z jednego źródła na inne miejsce, do jakiegoś innego obszaru. A więc w tym ujęciu tłumacz lub pośrednik ma za zadanie przenieść jakiś sens, jakieś znaczenie, zakorzenione w jednym miejscu do innego, otoczonego innym kontekstem (Tomaszkiewicz 2006, s. 64-65).

Tłumacz ma zatem możliwość korzystania z różnych sposobów przekładu tekstu bez konieczności zastępowania kłopotliwego słowa całkowicie korespondującą z nim ekwiwalentną jednostką leksykalną. Właśnie strategie przekładowe stanowia $\mathrm{w}$ niniejszym materiale główny przedmiot rozważań, które będą koncentrowały się również na przyczynach stosowania eufemizacji oraz na konsekwencjach tego zabiegu.

Źródło materiału badawczego stanowi jeden z paralelnych korpusów językowych InterCorp10 (wersja czesko-polska) utworzony w ramach Czeskiego Korpusu Narodowego (por. https://kontext.korpus. $\mathrm{cz} /$ first form? corpname=intercorp_v10_cs). Badaniu zostały poddane wyłącznie przekłady literatury pięknej, co zostało podyktowane dbałością o poziom przekładu. Trudno bowiem uznać za rzetelne dominujące $w$ korpusie przekłady o charakterze audiowizualnym (napisy do filmów), których autorzy najczęściej podpisują się jedynie pseudonimem lub nickiem, a które - po lekturze - okazują się obarczone wieloma błędami wynikającymi najczęściej z niedostatecznej znajomości języka czeskiego. Należy podkreślić, że przedmiot badań stanowią jedynie bezpośrednie przekłady z języka czeskiego na polski, a nie czeskie i polskie przekłady z innych języków (np. z języka angielskiego), które także są rejestrowane w czesko-polskiej wersji korpusu InterCorp.

Analizie poddano przekłady dwóch wybranych leksemów (srát, děvka) oraz wyrażenia przyimkowego (do prdele), które są zarejestrowane w słownikach języka czeskiego ${ }^{3} \mathrm{z}$ kwalifikatorem wulgarności

${ }^{3}$ Slovník současné češtiny (2011, Lingea, Brno) - dalej: SSoČ, Slovník spisovné češtiny pro školu a veřejnost (2013, wydanie studenckie, reedycja zgodna z wydaniem 2003 roku, Academia, Praha) - dalej: SSpČ i Slovník nespisovné češtiny (2006, Maxdorf, Praha) - dalej: SNČ. 
lub grubiańskości. Na taki, a nie inny wybór wpłynął bogaty i różnorodny (często charakteryzujący się wieloznacznością) materiał ilustracyjny dostarczający przykładów nie tylko samego użycia, ale i strategii przekładowych.

\section{SRÁT}

Czasownik srát rejestrowany jest $\mathrm{w}$ następujących słownikach:

a) SSoČ z kwalifikatorem vulg.: 1. vyměšovat výkaly 2 . nedbat, nevážit si, opovrhovat 3. zlobit, štvát, popuzovat, dopalovat.

b) SNČ (bez kwalifikatora): 1. kálet 2. rozčilovat, štvát někoho, vadit někomu 3. nemít zájem, nestarat se o něco či někoho, ignorovat něco.

W obydwu słownikach powtarzają się zatem trzy znaczenia:

- wydzielać odchody,

- lekceważyć coś/kogoś,

- denerwować kogoś.

Stownik czesko-polski autorstwa Janusza Siatkowskiego i Mieczysława Basaja, uwzględniając wulgarny (kwalifikator wulg.) charakter tego słowa, podaje dla niego następujące polskie ekwiwalenty: 1. srać 2. mieć w dupie (nosie), chromolić (co, kogo), kichać (na co, kogo) 3. denerwować, złościć (Siatkowski, Basaj 2002, s. 742).

Objaśniając znaczenia nazwy tej czynności, autorzy zastosowali zatem wulgarną nazwę wprost (znaczenie nr 1), co stanowi przykład całkowitej korespondencji; frazeologizm zachowujący ładunek ekspresyjny słowa przy jednoczesnym podaniu możliwości zamiany jednego ze składników eufemistycznym synonimem (znaczenie $\mathrm{nr} 2$ ) oraz nazwę neutralną (znaczenie nr 3), co również można uznać za sposób eufemizacji.

W poddawanym analizie materiale dla ostatniego (3) z wymienionych znaczeń (denerwować, złościć kogoś) niektórzy thumacze wykorzystali w przekładzie skale 1:1, zachowujac w ten sposób charakterystyczny dla danego czasownika ładunek ekspresji, na przykład:
1. Víte, pane Hrabal, to je pro vás ... ale to fotografování na hranicích v Rozvadově, to nás sere. $\left(\mathrm{Hrabal}^{4}\right)$

Wie pan, to dla pana ... ale to fotografowanie na granicy w Rozvadovie, to nas wkurwia.

2. “Když von mě tak sral," řekla mi. (Škvorecký)

- On mnie tak strasznie wkurwial - powiedziała mi.

3. Lepáku, vypal, moc se sereš. (Škvorecký)

- Pierdol się, baranie, bo już mnie wkurwiasz.

Część dokonała jednak „higienizacji przekładu” (por. Maliszewski 2007, s. 48), stosując eufemizację:

1. Řekl, že se mu líbí, jedině ho sere, že si přitom vždycky musí šlápnout na jazyk. (Škvorecký)

On odparł, że mu się nawet w sumie podoba, tylko go wkurza, że wymawiając je, musi tak strasznie łamać sobie język.

2. “Tohle mě vážně sere,” řekl upřímně Ignác. (Viewegh)

- Naprawde mnie to wkurza - powiedział otwarcie Ignac.

3. "Stř́brnej, neser!" vykřikl kdosi do dupotu nohou. (Viewegh)

- Strzibrny, nie wkurzaj nas! - zabrzmiało pośród tupotu nóg.

4. "Neser, Juraji," pravil pedagogicky řidič. (Škvorecký)

- Nie wpieprzaj mnie, Juraj - odezwał się pedagogicznie kierowca.

5. Páni, mě už to sere. (Škvorecký)

- Panowie, mam już tego dosyć.

Wród powyższych przykładów poza ekwiwalencją jednowyrazową pojawia się eufemizacja w postaci wielowyrazowej (mam już tego dosyć), która stanowi przykład neutralizacji i uniknięcia przekładu kłopotliwego słowa. Zaskoczenie budzi jednak użycie jako polskiego ekwiwalentu formy wpieprzać kogoś (przykład nr 4). Tłumacz, chcąc znaleźć odpowiednik jak najbardziej zbliżony do oryginału, ale jednocześnie pragnąc w pewien sposób złagodzić jego wulgarność, dokonał chybionego wyboru. Jednostka wpieprzać coś, kogoś (w formie dokonanej-wpieprzyć) jest rejestrowana w Stowniku polskich przekleństw i wulgaryzmów Macieja Grochowskiego (Warszawa 1995), jednak jej

${ }^{4}$ Mimo że materiał badawczy został wyekscerpowany z korpusu InterCorp, $\mathrm{w}$ celu jego przybliżenia, przy fragmentach w języku oryginału podaję nazwisko autora dzieła literackiego. 
znaczenie „ktoś spowodował, że coś a. ktoś jest w jakimś miejscu” nie odpowiada czeskiemu oryginałowi ${ }^{5}$. Ponadto brak argumentu przy czeskim czasowniku (Neser, Juraji, a nie: Neser mě, Juraji) wskazuje na inne niż podawane w wymienionych czeskich słownikach znaczenie, a mianowicie: mówić głupstwa bądź kłamać, a jego ekwiwalentem przekładowym przy całkowitej korespondencji powinien być wulgaryzm pierdolić (zob.: Grochowski 1995, s. 112) lub - w wersji zeufemizowanej - pieprzyć (zob.: Grochowski 1995, s. 110).

Problem ten dotyczy także przykładu "Střibrnej, neser!" vykřikl kdosi do dupotu nohou (przykład nr 3), gdzie tłumacz również zasugerował się jednym ze słownikowych znaczeń omawianego czasownika, nie wnikajac w strukture predykatywno-argumentowa wypowiedzi i posłużył się strategią dopowiedzenia (Strzibrny, nie wkurzaj nas!). Czasownik srát w znaczeniu denerwować kogoś jest bowiem dwuargumentowy (někdo, néco sere někoho), a brak drugiego argumentu $\mathrm{w}$ oryginale zmienia jego semantykę. Koncentracja obydwu tłumaczy na znalezieniu ekwiwalentu dla słowa wulgarnego przywiodła zatem do błędu.

Już powyższe przykłady wskazują na trudności, z jakimi boryka się autor przekładu w procesie tłumaczenia wulgaryzmów i znalezienia dla nich właściwego środka wyrazu.

Warto w tym miejscu zwrócić uwagę na różnorodność wyrażeń eufemistycznych w zakresie nacechowania stylistycznego i emocjonalnego. Są wśród nich wyrażenia ironiczne oraz lekceważąco-pogardliwe, od których ,niedaleka już droga do bardzo specyficznych form eufemistycznych, mianowicie takich, które od wulgarnych dzieli jedynie bardzo płynna granica, sytuująca się różnie w zależności od typu środowiska społecznego. Są to formy grubiańskie lub nawet zwulgaryzowane, a ich funkcja łagodząca jest mocno osłabiona" (De-

${ }^{5}$ W takim użyciu (denerwować kogoś) fraza pojawiła się w skeczu Prof. Jan Miodek Kabaretu Pod Wyrwigroszem. Data premiery skeczu jest jednak trudna do ustalenia i nie wiadomo, czy miała ona miejsce przed dokonaniem przekładu w 2004 roku: https://www.youtube.com/watch?v=LfdgP_vTEfY. mbska 2007, s. 244). Anna Engelking (1984, s. 127) twierdzi nawet, iż „eufemizmy neutralne uczuciowo są dość rzadkie”. Taką grubiańską formą eufemizmu jest na przykład przytaczany powyżej czasownik pieprzyć ${ }^{6}$. Eufemizmy bowiem mogą prezentować różny sposób oddalenia ekspresyjnego od verbum proprium.

W wyekscerpowanym materiale wystąpiły również przykłady użycia analizowanego czasownika w pozostałych znaczeniach:

a) 'vyměšovat výkaly' (wydzielać odchody):

1. Neser, čeče (Škvorecký).

- Nie rób w portki, bracie.

2. „Blbče, neser,” řekl Harýk. - Nie rób w portki, idioto - rzekł Haryk (Škvorecký).

Tłumacz zdecydował się na złagodzenie wulgaryzmu poprzez zastąpienie go potoczną jednostką frazeologiczną;

b) 'nedbat, nevážit si, opovrhovat' (lekceważyć):

1. Už na to serem! (Škvorecký).

Już to olewamy.

2. ,Seru na parádu a nejsem jako vy šašek s bílým límečkem a kravatou,” odsekl kameraman. (Kundera).

- Kicham na formy i pozory, nie jestem, jak pan, błaznem w białym kołnierzyku i w krawacie! - odgryzł się operator.

W pierwszym przykładzie autor przekładu złagodził wulgarność oryginału, wybierając tożsamy znaczeniowo, niekwalifikowany jako wulgarny, a jedynie pospolity ekwiwalent olewać (https://sjp.pwn.pl/ slowniki/olewać.html), który jednak w pewnych sytuacjach komunikacyjnych (w zależności od np. wieku czy statusu społecznego uczestników aktu) może być traktowany jako co najmniej grubiański. W drugim przykładzie natomiast dokonano dalej idącej eufemizacji przy użyciu frazeologizmu.

\footnotetext{
${ }^{6}$ Autor Stownika polskich przekleństw i wulgaryzmów charakteryzuje ten leksem jako posp./wulg., czyli „rodzaj wulgaryzmu systemowego (właściwego) o relatywnie niskim stopniu nacechowania, inaczej: jednostka na ogół uważana za wulgarną - w kulturalnym kręgu rozmówców, zwłaszcza starszego i średniego pokolenia" (Grochowski 1995, s. 31), ale równocześnie jako euf. (eufemizm).
} 
Badany materiał dostarczył także przykładu użycia omawianego leksemu w nowym, nierejestrowanym w słownikach języka czeskiego znaczeniu: srát se s néčím - pol. srać się z czymś' 'zajmować się czymś/kimś zbyt długo; obchodzić się z czymś/kimś zbyt delikatnie' (por. Grochowski 1995, s. 147):

Přece se s nim nebudeš srát vo dovolený (Viewegh).

- Przecież nie będziesz się z nim bić z takiego powodu.

Autor przekładu zachował się jednak bardzo powściagliwie i wybrał rozwiązanie, które zmienia sens wypowiedzi. „Bić się z kimś z jakiegoś powodu" nie jest bowiem tożsame znaczeniowo z czeskim oryginałem, w którym wyraźnie określono czas (do dovolený), co wskazuje właśnie na znaczenie ,zajmować się czymś/kimś zbyt długo”. Próba znalezienia odpowiedniego ekwiwalentu dla wulgaryzmu po raz kolejny doprowadziła zatem do sytuacji, kiedy nastąpił, co prawda, transfer słowa, ale nie sensu.

\section{DĚVKA}

W SSoČ rzeczownik ten jest rejestrowany z kwalifikatorem zhrub. w znaczeniu: prostitutka, žena nevalné pověsti. Natomiast w SNČ, uwzględniającym obraźliwy (uwłaczający) charakter tej nominacji (kwalifikator hanl.) pojawiają się trzy znaczenia: 1. prostitutka, také žena, která často stř́ídá partnery 2 . nadávka či hanl. označení ženy, někdy však i o muži, který využívá cizích problémů 3. vězeň. podřadný vězeň, uklizeč.

Bezpośrednim ekwiwalentem tej nominacji w odniesieniu do kobiety jest zatem w języku polskim nazwa dziwka. W Słowniku języka polskiego $P W N$ rzeczownik ten jest rejestrowany z kwalifikatorem obraźl. lub posp.:

1. obraźl. „o kobiecie, której postępowanie uważa się za niemoralne lub oburzające";

2. posp. ,prostytutka” (https://sjp.pwn.pl/szukaj/dziwka.html).
Wyekscerpowany z korpusu InterCorp materiał badawczy dostarcza jednak zaskakujących rozwiązań przekładowych:

1. Ale to bylo v jiné zemi, a mimo to, ty děvky... (Škvorecký).

Ale to było w innym kraju, a poza tym te dziewczyny..

2. Jeníčku, Jeníčku! Macatá děvka, to je můj celý život (Hašek).

- Jasiu, Jasiu, taka pulchna dziewczynka, to uciecha nad uciechami.

3. Za deset minut tu byl taxík a Ambroz odjel s děvkou a s Vargou (který tvrdil, že s ním žádná holka nepůjde) do smluvené hospody na druhém konci Ostravy za Čeňkem (Kundera)

Po dziesięciu minutach zajechała taksówka i Ambroży odjechał z dziewczyna i z Vargą (który twierdził, że z nim żadna babka nie pojedzie) do umówionej gospody na drugim końcu Ostrawy, w ślad za Wickiem.

4. Na Bezděz by $\mathrm{k}$ nim děvky měly daleko a $\mathrm{v}$ noci by ožralí nevylezli na vrch (Durych).

$\mathrm{Na}$ Bezdiez dziewuchom było by do nich za daleko, a oni w nocy w dodatku pijani nie wdrapali by się pod górę.

5. Házeli ho po garnizónách, kde vůbec neměl nic jiného na práci než v garnizónním chrámu jednou za čtrnáct dní před mší kázat vojákům z posádky a odolávat pokušení, které vycházelo z důstojnického kasina, kde vedly se takové řeči, že $\mathrm{v}$ porovnání s nimi byly macaté děvky jeho faráře nevinnou modlitbičkou $\mathrm{k}$ andělu strážci (Hašek).

Przerzucali go z garnizonu do garnizonu, gdzie w ogóle nie miał nic do roboty, chyba że co jakie dwa tygodnie wygłaszał kazanie dla żołnierzy, a sam ćwiczy się, aby mógł stawiać czoło pokusom wychodzącym z kasyna oficerskiego, gdzie gadano o takich sprawach, że pulchniutka dziewczyna proboszcza była w porównaniu $z$ tym po prostu niewinną modlitwą dla anioła stróża.

6. Měl těch písní balík, který mu zde zanechal na rozdávání procházejícím vojenským oddílům nějaký vysoký vojenský církevní hodnostář, projíž- dějící se zpustošenou Haličí na automobilu s nějakými děvkami (Hašek).

Miał tych pieśni całą pakę, bo pozostawił je u niego - z myślą o rozdaniu ich przechodzącym wojskom - jakiś wysoki wojskowy dostojnik kościelny, przejeżdżający przez opustoszałą Galicję samochodem w towarzystwie jakichś kobiet.

7. Zalétla pohledem $\mathrm{k}$ té děvce (Viewegh). Spojrzała w stronę Denisy.

Poza ostatnim przykładem, gdzie autor tłumaczenia pominął kłopotliwą nazwę i zastąpił ją nazwą własną (imieniem), pozostali tłumacze jako ekwiwalent wybrali nazwę ogólną osoby płci żeńskiej: dziewczyna, dziewucha oraz kobieta jako swojego rodzaju hiperonim grubiańskiego oryginału. Takiego wyboru nie wyjaśnia jednak nawet aso- 
cjacja fonetyczna z polskim wyrazem dziewka, ponieważ żadne z jego znaczeń nie jest tożsame z nazwą ogólną dziewczyna ${ }^{7}$ czy kobieta ${ }^{8}$ :

1. daw. „kobieta rozwiązła”;

2. daw. „niezamężna dziewczyna pracująca jako służąca na wsi” (https://sjp.pwn.pl/szukaj/dziewka.html)

Akceptowalnym jest natomiast drugi $\mathrm{z}$ podanych przykładów tłumaczenia - dziewczynka, który w języku polskim ma następujące znaczenia:

1. „dziecko płci żeńskiej”,

2. „córka”,

3. pot. ,żartobliwie, z odcieniem poufałości o młodej kobiecie”,

4. euf. ,,prostytutka” (https://sjp.pwn.pl/szukaj/dziewczynka.html),

choć trudno jednoznacznie stwierdzić, czy to ostatnie znaczenie rzeczywiście przesądziło o wyborze tłumacza.

Pozostałe ekwiwalenty jednak nie oddają sensu wypowiedzi w języku oryginału. Trudno wnioskować, by przyczyną tego stanu rzeczy było zjawisko „fałszywych przyjaciół tłumacza” (cz. divka - pol. dziewczyna; cz. děvka - pol. dziwka), ponieważ mamy do czynienia z oficjalnie publikowanymi przekładami dokonywanymi przez profesjonalnych tłumaczy. Jest to zatem mało prawdopodobne, choć nie niemożliwe. Ponadto w przykładzie piątym zmieniono kategorię liczby z mnogiej na pojedynczą: macaté děvky - pulchniutka dziewczyna, co również można uznać za rodzaj eufemizacji.

\section{DO PRDELE}

Wyrażenie jest rejestrowane w SsoČ i SNČ jako przekleństwo. Występuje też w konstrukcji wykrzyknikowej jdi do prdele!, której

\footnotetext{
${ }^{7}$ Dziewczyna: „1. młoda kobieta, zwłaszcza niezamężna. 2. czyjaś sympatia lub narzeczona. 3. pot. pomoc domowa" (https://sjp.pwn.pl/szukaj/dziewczyna.html).

${ }^{8}$ Kobieta: „1. dorosły człowiek płci żeńskiej. 2. pot. żona” (https://sjp.pwn.pl/ szu kaj/kobieta.html).
}

strategie tłumaczeniowe również zostaną omówione. Należy wyjaśnić, że sam czeski rzeczownik prdel to wulgarne określenie części ciała, na której się siada (pol. dupa).

Dla samego wyrażenia do prdele w funkcji przekleństwa polskim ekwiwalentem jest występujące w funkcji parentezy wyrażenie kurwa! i niektórzy tłumacze decydują się na jego zastosowanie w przekładzie:

1. Přemejšlím, na co bych se tak ještě do prdele zeptal (Viewegh). Zastanawiam się, o co jeszcze, kurwa, spytać

\section{W większości przekładów dominuje jednak eufemizacja:}

1. Jen zdálky ještě zaslechla, jak kameraman říká: “Do prdele ...” (Kundera). $Z$ daleka usłyszała jeszcze tylko, jak operator mówił: Kurczę blade ...

2. "Do prdele!" zvolal jsem (Škvorecký).

- Do diabła! - zawołałem.

3. Něco řekl, asi Do prdele! (Škvorecký).

Coś powiedział, chyba "A niech to!"

4. A do prdele! Já, pane, jsem liberální člověk (Škvorecký).

W tyłek! Ja, mój panie, jestem człowiekiem liberalnym.

5. Rodinné štěstí všech předcházejících generací je založeno právě na tomhle modelu tak se ho do prdele nesnaž měnit! (Viewegh)

Rodzinne szczęście wszystkich poprzednich pokoleń opierało się właśnie na tym modelu, więc nie próbuj go, do cholery, zmieniać!

6. Do prdele, nech mě bejt! (Škvorecký).

Kurde, weź się ode mnie odwal!

7. Posloucháš mě do prdele vůbec? (Viewegh).

Kurde, czy ty mnie w ogóle słuchasz?

Wśród tej grupy przykładów najmniej adekwatnym wydaje się wyrażenie $w$ tyłek (przykład nr 4). Jest ono bowiem zeufemizowaną kalką oryginału przekleństwa, zupełnie nieoddającą jego sensu. Wyrażenie to nie funkcjonuje bowiem w języku polskim w funkcji przekleństwa. Można „,wchodzić/włazić komuś w tyłek”, ,,pocałować kogoś w tyłek” czy „,kopać kogoś w tyłek”, ale jako wykrzyknienie ekwiwalent ten nie jest tożsamy znaczeniowo z czeskim oryginałem.

Eufemizacja wulgarnego oryginału odbywa się natomiast bądź przez wykorzystanie ekwiwalentu będącego w języku polskim eufe- 
mizmem parentezy kurwa (kurczę, kurde), bądź łagodniejszego przekleństwa do cholery! (zob.: Grochowski 1995, s. 44) lub do diabła! (zob.: Grochowski 1995, s. 55), lub poprzez niedopowiedzenie, swoiste pominięcie kłopotliwego elementu (a niech to!).

Eufemizacja ma miejsce również w przypadku wspominanej konstrukcji jdi (běž) do prdele! Profesorowie Janusz Siatkowski i Mieczysław Basaj w przywoływanym już wcześniej Słowniku czesko-polskim podaja jej następujące znaczenia: idź do diabła (do cholery)!, odczep się!, odpieprz się! (Siatkowski, Basaj 2002, s. 565). Już zatem wyjaśnienie słownikowe stanowi przykład eufemizacji tej konstrukcji, której bezpośrednim ekwiwalentem jest w języku polskim forma spierdalaj! lub odpierdol się! (http://www.preklady-polstina-cestina.cz/polsky_slovnik_sprostych_slov.html). Potwierdza to Stownik polskich przekleństw $i$ wulgaryzmów, gdzie wśród różnych znaczeń wulgaryzmu odpierdolić autor podaje następujące:

[...] ktoś odpierdolił się od kogoś a. czegoś [dk] 'ktoś odczepił się od kogoś a. czegoś', 'ktoś zostawił kogoś a. coś w spokoju’ (Grochowski 1995, s. 105).

Sposoby uniknięcia bezpośredniej ekwiwalencji przekładowej tej konstrukcji są następujące:

\section{Jděte do prdele taky! (Hrabal).}

Idźcie do diabła!

2. Jděte do prdele oba, nedostanete nic! (Hrabal).

Idźcie do diabła obaj, nie dostaniecie nic!

3. Jděte do prdele! ... a on se zvedl jako pták Fénix ... (Hrabal) Spieprzaj pan! ... a on wstał jak ptak Feniks..

4. Tak at' si dou s ef ó do prdele! A tak se ze všech kandidátů, kteří se ve třináct hodin měli seřadit před budovou a pod velením rotného odpochodovat na politické oddělení, seřadil pouze jediný vojín prvního ročníku (Škvorecký).

Niech się sami udławią tą odznaką! I tak oto spośród wszystkich kandydatów, którzy o trzynastej mieli się zgromadzić przed budynkiem, aby stamtąd pod dowództwem sierżanta odmaszerować do pomieszczenia wydziału politycznego, zgromadził się tylko jeden, szeregowiec z pierwszego rocznika.

5. "Di do prdele," pravil Benno. (Škvorecký).

- A idźże! - zgasił mnie Benno.

6. Běž do prdele! (Viewegh).

$$
\text { A goń się! }
$$

Jak już zostało wspomniane, konstrukcja ta jest w języku czeskim wulgarnym wyrażeniem chęci pozbycia się kogoś i zarówno jej ekwiwalent spieprzaj (w zależności od odbiorcy komunikatu traktowany jako wulgaryzm pospolity bądź eufemizm; zob. Grochowski 1995, s. 145) oraz idźcie do diabła są tożsame z jej znaczeniem.

Ciekawym sposobem eufemizacji tego wyrażenia jest uniknięcie przekładu kłopotliwego elementu prdel poprzez użycie wykrzyknień A idżże! czy - w sposób mniej subtelny: A goń się! (zob. Czeszewski 2008, s. 105).

Wśród powyższych przykładów występuje również konstrukcja „niech się sami udławią” (przykład nr 4). Ow frazeologizm (udław się!) jest w języku polskim używany „w sytuacji, gdy ktoś nie może uzyskać od kogoś tego, na czym mu bardzo zależy" (Kłosińska, Sobol, Stankiewicz 2005, s. 582). Jest to formuła złorzeczenia, która nie oddaje jednak sensu czeskiego oryginału. Tu bowiem (na co wskazuje kontekst) chodzi o sytuację odwrotną: ktoś nie chce przyjąć tego, co ktoś zamierza mu dać.

Tłumaczenie niewygodnych, kłopotliwych, uznawanych za wulgarne lub grubiańskie jednostek odbywa się zatem poprzez:

- zamianę jednostki eufemistycznym ekwiwalent e m j e d now y r a z o w y m, np. srát někoho - wkurzać kogoś; srát na něco/někoho - kichać na coś/kogoś;

-zamiane jednostki jednowyrazowej e ufemistyczną jednostką wielowyrazową (frazeologizmem), np. srát-robić w portki;

- oddanie sensu wypowiedzi poprzez zastosowani e n e utrali z a c j i, np. mě už to sere-mamjuż tego dosyć);

- pomini ęc i e w u 1 garyzmu w przekładzi e, np. ktéděvce - w stronę Daisy; jdi do prdele! - a idźże!;

- z a mianę nazw y s z c z e gół ow e j o gólną: děvka-dziewczyna, kobieta, dziewucha.

Stosowanie eufemizacji bez watpienia wpływa na stylistykę tekstu, ładunek emocjonalny treści, ale może również (co zostało wykaza- 
ne w prezentowanym materiale) prowadzić do zmiany sensu oryginału. Trudno znaleźć powody stosowania tego zabiegu poza walorami estetycznymi uzyskanego w ten sposób przekładu. Wydaje się, że jedyna przyczyną jest autocenzura tłumacza motywowana jego wrażliwością. Należy jednak pamiętać, że

[...] celem przekładu jest poznanie obcego i inspiracja w stosunku do rodzimej wyobraźni artystycznej i intelektualnej; służy wzbogaceniu komunikacyjnemu dzięki rol empatii w thumaczeniu, co dowodzi potrzeby porozumienia na drodze transgresji. $\mathrm{W}$ istocie więc przeciwna jest przekładowi idea tabu, ponieważ otwiera odbiorce $\mathrm{n}$ obcość i nieznane; tabu zaś zamyka jednostkẹ w kręgu podporządkowujacej praktyki, dając poczucie bezpieczeństwa. Przekład stanowi zatem jego odwrotność, przekraczając różne granice, począwszy od granic języka (Tokarz 2007, s. 7).

Alexander Fraser Tytler (2014, s. 48) twierdzi wręcz, że przekład idealny oddaje nie tylko myśli i emocje autora, ale również jego styl i sposób pisania. Stosowanie eufemizacji - na co wskazuje przedstawiony materiał - może w rożnym stopniu ów rezultat ,idealnego przekładu" zaburzać.

\section{Literatura}

C rne k F., 1927, Ze studyów nad eufemizmami w językach słowiańskich. „Sprawozdania Towarzystwa Naukowego we Lwowie", nr 7.

C z e s z e w s k i M., 2008, Slownik polszczyzny potocznej, Warszawa.

C zy żew sk i F., Ty r pa A. (red.), 2008, Tabu językowe i eufemizacja $w$ dialektach stowiańskich, Lublin.

D ą b row s k a A., 1994, Eufemizmy wspótczesnego języka polskiego, Wrocław.

D e m b sk a K., 2007, Rosyjsko-polski stownik eufemizmów semantycznego pola seksu, Torun.

Eng e $1 \mathrm{king}$ A., 1984, Istota i ewolucja eufemizmów (na przykładzie zastępczych określeń śmierci), „Przegląd Humanistyczny” 4, s. 115-129.

F r a s e r T y t l e r A., 2014, Esej o zasadach sztuki przekładowczej, thum. K.F. Rudolf, Gdańsk.

G r o c h o w s k i M., 1995, Stownik polskich przekleństwi wulgaryzmów, Warszawa.

Kło s iń sk a A., S o bol E., S t a n ki e w i c z A., 2005, Wielki stownikfrazeologiczny $P W N$ z przystowiami, Warszawa.

L e s z c z y ń s k i Z., 1988, Szkice o tabu językowym, Lublin.
Mal is ze w ski J., 2007, Wulgaryzmy - tabu w pracy thumacza (na przykładzie angielskich tlumaczeń intralingwalnych, [w:] Tabu w przektadzie, red. P. Fast, N. Strzelecka, Katowice-Częstochowa.

S i a t k ow s k i J., B a s a j M., 2002, Stownik czesko-polski, Warszawa.

S o j d a S., 2012, Kontrasty eufemistyczno-dysfemistyczne w lingwistyce stowackiej i polskiej. „Linguarum Silva”, nr 1.

S z y m c z a k-R o z la ch M., 2014, Eufemizmy we wspótczesnym języku slowackim, Katowice.

To k a r z B., 2007, Tabu i autocenzura $w$ przekładzie, [w:] Tabu w przektadzie, red. P. Fast, N. Strzelecka, Katowice-Częstochowa.

To m a s z k i e w i c z T., 2006, Przekład audiowizualny, Warszawa.

W i d ła k S., 1963, Tabu i eufemizm w językach nowożytnych. „Biuletyn Polskiego Towarzystwa Językoznawczego" 22.

А л е к с е е н к о М., 1999, Эвфемизация современной газетно-публицистической речи, [в:] Проблемы нормы и теории в практике... Теория языковой вариантивности..., Szczecin.

В и д л а к С., 1967, Проблема эвфемизма на фоне теории языкового поля, [в:] Этимология 1965. Материаль и исследования по индоевропейским и другим языкам, ред. О.Н. Трубачёв, Москва.

К ры с и н Л.П., 1996, Эвфемизмы в современной русской речи, [в:] Русский язык кониа ХХ столетия, ред. Е. Земская, Москва.

Л а р и н Б.А., 1961, Об эвфемизмах, [в:] Проблемы языкознания. Сборник в честь академика И. И. Мещанинова, Ленинград. 